\title{
Drip Irrigation and Fertigation Effects on Aerobic Rice (Oryza sativa) in Semi-Arid Conditions of Telangana State, India
}

\author{
B. Padmaja* and M. Malla Reddy \\ Department of Agronomy, College of Agriculture, Prof. Jayashankar Telangana State \\ Agricultural University, Rajendranagar, Hyderabad-030, Telangana State, India \\ *Corresponding author:
}

\section{Keywords}

Aerobic rice, Drip

irrigation,

Fertigation,

Nitrogen-use

efficiency, Root

volume, Water-use

efficiency and Yield

Article Info

Accepted:

08 July 2018

Available Online:

10 August 2018

\section{A B S T R A C T}

A field experiment was conducted during rainy season of two consecutive years (2011 and 2012), in sandy loam soils of Warangal, Telangana State to study the response of aerobic rice (Oryza sativa L.) to drip irrigation and nitrogen fertigation under semi-arid environment. The experiment was laid out in split plot design with four replications. Three irrigation schedules viz. drip irrigation at 100\% Pan Evaporation (PE); 150\% PE and 200\% $\mathrm{PE}$ were taken as main plots and three nitrogen levels through fertigation viz. 90, 120 and $150 \mathrm{~kg} / \mathrm{ha}$ were taken as subplots. The data revealed that the growth parameters of aerobic rice like LAI, SPAD chlorophyll meter reading, tillers $/ \mathrm{m}^{2}$ and drymatter accumulation were significantly higher in $200 \%$ PE schedule compared to that of $100 \%$ PE but comparable with $150 \%$ PE except for drymatter accumulation. Drymatter accumulation at maturity, root volume and dry weight were more at $200 \%$ PE compared to that of lower schedules. The number of panicles $/ \mathrm{m}^{2}$ and filled spikelets/ panicle increased from $100 \%$ PE to $150 \%$ PE but not at 200\% PE while sterility of spikelets was higher with $100 \%$ PE schedule. Higher grain and straw yield, nitrogen uptake and economics were recorded with 200\% PE over the other two schedules. Irrespective of the irrigation schedules, growth parameters (plant height, LAI, SPAD meter reading, tillers $/ \mathrm{m}^{2}$ and drymatter accumulation), yield attributes (panicles $/ \mathrm{m}^{2}$, panicle length and filled spikelets/panicle) increased with level of $\mathrm{N}$ application from 90 to $120 \mathrm{~kg} \mathrm{~N} / \mathrm{ha}$ while root volume and dry weight were higher at $150 \mathrm{~kg} \mathrm{~N} / \mathrm{ha}$. The number of days taken to reach 50 per cent flowering was not influenced by irrigation schedules but influenced by the nitrogen levels during first year in which the plots supplied with $150 \mathrm{~kg} \mathrm{~N} / \mathrm{ha}$ flowered earlier than other $\mathrm{N}$ levels. The sterility of spikelets was higher at $90 \mathrm{~kg} \mathrm{~N} / \mathrm{ha}$ compared to other doses. Grain yield, straw yield, nitrogen uptake and economic parameters were higher at $150 \mathrm{~kg}$ $\mathrm{N} /$ ha compared to lower $\mathrm{N}$ levels. Water use-efficiency reduced with increased water input from 100\% PE schedule to 200\% PE but increased with the increase in N level from 90 to $150 \mathrm{~kg} \mathrm{~N} / \mathrm{ha}$ during both the years of study. In contrary, nitrogen use efficiency was enhanced with the increase in water input in drip irrigation and reduced with the increase in $\mathrm{N}$ level of application. Gross returns, net returns and benefit: cost ratio were higher in drip irrigation schedule of $200 \% \mathrm{PE}$ and $150 \mathrm{~kg} \mathrm{~N} / \mathrm{ha}$ closely followed by that realized at $120 \mathrm{~kg} \mathrm{~N} /$ ha in the same irrigation schedule. 


\section{Introduction}

Traditional rice production involves submerged conditions with approximately 5 to $10 \mathrm{~cm}$ deep standing water throughout the crop growth period. This system requires around 3000 to 5000 litres of water for producing one $\mathrm{kg}$ of grain which is about twice or even more than that for wheat or maize (Joshi et al., 2009). It is the single largest user of fresh water consuming about 30 per cent and more than 45 per cent of total fresh water used in World and Asia, respectively (Barker et al., 1999). The increasing scarcity of fresh water for agriculture and the competing demand from the non-agricultural sector threaten the sustainability of the irrigated rice ecosystem. To cope up with scarcity, several water saving technologies have been developed for rice.

The International Rice Research Institute (IRRI) developed aerobic rice technology, wherein the crop is established in nonpuddled, non-flooded fields and rice is grown like an upland crop with adequate inputs and supplementary irrigation when rainfall is insufficient (Bouman and Tuong, 2001 and Prasad, 2011). Farmers in Brazil, China and India are pioneering this system where water is scarce or costly. Aerobic rice cultivation saves water input and increases water productivity by reducing water use during land preparation and limiting seepage, percolation and evaporation (Peng et al., 2012). It also reduces labour requirement and greenhouse gaseous emission from rice field. However, many recent studies have revealed a yield penalty of rice under aerobic cultivation (George et al., 2002; Belder et al., 2005; Peng et al., 2006 and Mallareddy and Padmaja, 2013). The shift from puddled to aerobic soil conditions brings profound changes in soil water status, aeration, soil organic matter turnover, nutrient dynamics, carbon impounding, weed flora and greenhouse gas emissions (Farooq et al., 2009 and Prasad, 2011).

To make aerobic rice successful, new varieties and new management practices need to be developed. Optimum irrigation scheduling and nitrogen nutrition is critical for profitable yield realization of irrigated rice ecosystems (Maheswari et al., 2008). Drip irrigation and fertigation methods have been proved to be the water and nutrient efficient methods, respectively in most of the crops apart from increasing the productivity. Aerobic rice with micro irrigation practices leads to sustainable rice production for immediate future to address water scarcity with more benefits and environmental safety in the scenario of global warming by reduced methane emission is an added advantage (Parthasarathi et al., 2012). Realising the need of increasing the water productivity, many State Governments are providing huge subsidies to farmers for drip irrigation.

In aerobic system, the dominant form of nitrogen is nitrate and relatively little ammonia volatilization is expected after fertilizer nitrogen application. The alternate moist and dry soil conditions may stimulate nitrification-denitrification processes in dry sown rice, resulting in loss of nitrogen through $\mathrm{N}_{2}$ and $\mathrm{N}_{2} \mathrm{O}$. The differences in soil $\mathrm{N}$ dynamics and pathways of nitrogen losses in dry sown rice system may result in different fertilizer nitrogen recoveries. With even high nitrogen applications in aerobic rice, grain filling may be limited by a low contribution of post-anthesis assimilates (Zhang et al., 2009). In addition, in the absence of transplanting, the roots of aerobic rice are located in the shallow surface soil, which results in a relatively low uptake of nitrogen (Zhang and Wang, 2002). Keeping this in view, an attempt was made to evaluate the performance of aerobic rice under drip irrigation and nitrogen fertigation. 


\section{Materials and Methods}

A field experiment was conducted during the rainy season of 2011 and 2012 at Regional Agricultural Research Station, Warangal $\left(18^{0} 00^{\prime} 53.2 " \mathrm{~N}, 79^{0} 36^{\prime} 17.2^{\prime \prime} \mathrm{E}\right.$ and $275 \mathrm{~m}$ above mean sea level), Telangana State, India. Climate of the study site is sub-tropical and semi-arid type with mean annual rainfall of $885 \mathrm{~mm}$ and a mean annual evaporation of $1621 \mathrm{~mm}$. Soil of the experimental field was sandy loam with $\mathrm{pH}$ of 7.9, Electrical conductivity (EC) $0.17 \mathrm{~d} \mathrm{~S} / \mathrm{m}$, low in organic C $(0.40 \%)$, available $\mathrm{N}(227 \mathrm{~kg} / \mathrm{ha})$, available $\mathrm{P}(11 \mathrm{~kg} / \mathrm{ha})$ and available $\mathrm{K}(65 \mathrm{~kg} / \mathrm{ha})$. The weekly mean maximum temperature ranged from $27.1^{\circ} \mathrm{C}$ to $33.0^{\circ} \mathrm{C}$ and $26.1^{\circ} \mathrm{C}$ to $30.6^{\circ} \mathrm{C}$ during 2011 and 2012, respectively. The mean minimum temperature for the corresponding period ranged from $22.3{ }^{\circ} \mathrm{C}$ to $26.1{ }^{\circ} \mathrm{C}$ and $20.0{ }^{0} \mathrm{C}$ to $26.0^{\circ} \mathrm{C}$, respectively, while the average maximum and minimum temperatures during the same period were $30.5{ }^{\circ} \mathrm{C}$ and 24.0 ${ }^{0} \mathrm{C}$ during 2011, and $28.7{ }^{\circ} \mathrm{C}$ and $23.3{ }^{\circ} \mathrm{C}$ during 2012 , respectively. The weekly mean relative humidity ranged from 60.1 to 81.1 per cent during 2011 and 74.6 to 80.3 per cent during 2012, while the average relative humidity was 72.7 per cent and 76.9 per cent, during 2011 and 2012, respectively. A total rainfall of $349.2 \mathrm{~mm}$ and $784.0 \mathrm{~mm}$ was received on 26 and 53 rainy days during 2011 and 2012, respectively. The total evaporation during the growing season of rice was 379 and $387.9 \mathrm{~mm}$ during 2011 and 2012, respectively. The weekly mean bright sunshine hours per day varied from 1.5 to 7.0 hours and 0.7 to 9.2 hours during 2011 and 2012, respectively. Treatments consisting of three irrigation regimes viz. drip irrigation at $100 \%$ Pan Evaporation (PE), 150\% PE and 200\% PE in main plots and three nitrogen levels through fertigation $(90,120$ and $150 \mathrm{~kg} / \mathrm{ha})$ in subplots were tested in a split-plot design and replicated four times. The cultivar used for the study was 'WGL 20471' (Erramallelu) with medium duration (120 days), fine grain, drought tolerant and good cooking quality.

The field was dry-ploughed and harrowed but not puddled during land preparation. Seed were sown in solid rows at a spacing of $30 \mathrm{~cm}$ between the rows in favourable soil moisture condition for germination. Thinning and gap filling was done at 10 days after sowing. Weeds were controlled by pre-emergence application of pendimethalin@ $1.2 \mathrm{~kg}$ a.i/ha followed by pyrazosufuron ethyl@ 30 g. a.i/ha at 20 days after sowing. Nitrogen was applied as per the treatments in the form of water soluble specialty fertilizers (urea phosphate and urea) as fertigation through ventury fitted to the drip system. The entire dose was split into ten equal parts and applied through drip at weekly interval starting from ten days after sowing. $\mathrm{P}_{2} \mathrm{O}_{5}$ was supplied @ $60 \mathrm{~kg} / \mathrm{ha}$ as urea phosphate during first fertigation uniformly to all the treatments. Potassium@ $50 \mathrm{~kg} \mathrm{~K}_{2} \mathrm{O} / \mathrm{ha}$ as muriate of potash was applied to all the treatments at the time of sowing as basal dose. To correct the 'Fe' deficiency which occurred at 20-30 DAS, ferrous sulphate was applied @ $5 \mathrm{~g} / \mathrm{lt}$ for three times at weekly interval. To control yellow mite, dicofol @3g/lt was sprayed at 50 DAS and to control blast, tricyclozole @0.6 g/lt was sprayed at 90 DAS.

Drip irrigation was given every alternate day as per the schedules based on the evaporation from open pan evaporimeter (USWB class A) situated at Regional Agricultural Research Station, Warangal. The laterals of $16 \mathrm{~mm}$ diameter were laid out at $60 \mathrm{~cm}$ apart with a spacing of $50 \mathrm{~cm}$ distance between two inline emitters. The emitter discharge was $4.0 \mathrm{lt} / \mathrm{hr}$ and application rate was $13.33 \mathrm{~mm} / \mathrm{hr}$. Control valves were fixed in all the plots to facilitate controlling the water flow as per the treatments. During rainy days, the quantity of water applied to each treatment was adjusted for the rainfall received. 
Data on growth, yield attributes, yield and $\mathrm{N}$ uptake were recorded at different intervals and crop maturity. Root volume (cc/hill) was measured by water displacement method as described by Misra and Ahmed (1987). The roots after recording the volume were kept in hot air oven at $60^{\circ} \mathrm{C}$ till the constant weight was obtained and expressed as g/plant. Standard procedures were used for chemical analysis of soil and plant samples. The economic parameters (gross returns, net returns and benefit: cost ratio) were worked out on the basis of prevailing market prices of inputs and outputs. Water use efficiency (WUE) was calculated as grain yield per total water received from rainfall and irrigation and expressed as: $\mathrm{WUE}=\mathrm{Y} / \mathrm{R}+\mathrm{I}$ (kg/ha-mm). Nitrogen-use efficiency (NUE) (kg grain/kg applied $\mathrm{N}$ ) was calculated using the equation: $\mathrm{NUE}=\mathrm{Y} / \mathrm{N}$; where $\mathrm{Y}$ is the grain yield $(\mathrm{kg} / \mathrm{ha}) ; \mathrm{R}$ is the amount of effective rainfall $(\mathrm{mm})$; I is the amount of irrigation water applied (mm) and $\mathrm{N}$ is the quantity of $\mathrm{N}$ applied $(\mathrm{kg})$. The data were analyzed by using the 'Analysis of Variance Technique' as per the procedures described by Panse and Sukhatme (1985). The treatments means were compared at $5 \%$ level of significance.

\section{Results and Discussion}

\section{Growth parameters}

Drip irrigation and $\mathrm{N}$ fertigation significantly influenced the growth parameters of aerobic rice. Plant height at 30 DAS, leaf area index (LAI), SPAD chlorophyll meter reading and number of tillers $/ \mathrm{m}^{2}$ at all the stages of observation were significantly increased in $200 \%$ PE compared to that of $100 \%$ PE but comparable with $150 \%$ PE during first year of experimentation (Fig. 1 to 5). During second year (2012), plant height, tiller number, SPAD chlorophyll meter reading at all the stages of observation and drymatter accumulation upto 90 DAS remained largely unaffected by the irrigation schedules. It is attributed to evenly distributed and $128 \%$ more rainfall than that received during first year which occurred upto panicle initiation stage. Hence, the effect of irrigation schedules could not be observed. However, drymatter accumulation at all the stages during first year and at maturity during second year was significantly higher with $200 \%$ PE schedule compared to the other two schedules. All the growth parameters viz. plant height, LAI, SPAD chlorophyll meter reading, number of tillers/ $\mathrm{m}^{2}$ and drymatter accumulation increased with the increase in $\mathrm{N}$ level from 90 to $120 \mathrm{~kg} \mathrm{~N} /$ ha (Fig. 6 to 10). Application of higher nitrogen dose result in taller plants and larger leaf area which increase in the photosynthate production in turn enhances the drymatter production in rice. The results are in consonance with that of Belder et al., (2005), Maheswari et al., (2008), Sathiya et al., (2008) and Kadiyala et al., (2012).

The number of days taken to reach 50 per cent flowering in aerobic rice did not differ due to irrigation schedules but differed by the nitrogen levels during 2011 in which the plots supplied with $150 \mathrm{~kg}$ N/ha flowered earlier than the plots which received $120 \mathrm{~kg}$ but was on a par with $90 \mathrm{~kg} \mathrm{~N} / \mathrm{ha}$ (Table 1).

\section{Root volume and dry weight}

Root volume (cc/hill) and dry weight (g/hill) of rice measured at $50 \%$ flowering was influenced by the irrigation schedules and nitrogen levels in fertigation (Table 1). Higher root volume was observed with drip irrigation at $200 \%$ PE which was significantly superior to that with $100 \%$ PE during both the years of study but differed with $150 \%$ PE only during 2012. This could be attributed to the congenial soil-moisture environment promoting root growth on account of additional water availability in higher irrigation schedule (Ghosh et al., 2012). The irrigation schedules 
of 100 and $150 \%$ PE were on a par with each other. Greater vigour of root has additional advantages encouraging root penetration to the deeper zone, which could accelerate extraction of subsurface soil water effectively (Bouman and Tuong, 2001 and Kato et al., 2007). Additionally, increased nutrient uptake and greater $\mathrm{N}$ use efficiency were also associated with better root development (Peng and Bouman, 2007 and Richards, 2008). Root volume measured in the plots where $150 \mathrm{~kg} \mathrm{~N} /$ ha was applied through fertigation was significantly superior to that in $90 \mathrm{~kg} \mathrm{~N} /$ ha during both the years and $120 \mathrm{~kg} \mathrm{~N} / \mathrm{ha}$ during 2011. Even, a small difference in root growth may result in large difference in water and nutrients uptake (Henry et al., 2011). The above results confirm the findings of Maheswari et al., (2008) and Mahajan et al., (2012).

\section{Yield attributes}

Yield attributes of aerobic rice were also influenced by irrigation schedules and nitrogen levels in drip fertigation. Number of panicles $/ \mathrm{m}^{2}$ were significantly higher at $200 \%$ PE compared to that of $100 \%$ PE but on par with that of $150 \%$ PE. Number of filled spikelets/ panicle increased upto $150 \% \mathrm{PE}$ during 2011 and upto 200\% PE during 2012 (Table 2). The percentage of sterile spikelets was higher in $100 \%$ PE schedule. Panicle length and test weight did not differ due to irrigation schedules. Higher number of panicles at $200 \%$ PE drip irrigation schedule might be due to favourable moisture conditions during panicle initiation stage which was beneficial in maintaining normal cell integrity, cell division and elongation apart from enhancing nutrient uptake (Singh, 2004) and finally led to increased sink size. A little water deficit at the anthesis stage of rice induce a high percentage of spikelet sterility and reduce grain yields (De Datta, 1989). Water stress at flowering affects physiological processes such as anther dehiscence (Ekanayake et al., 1990), pollen germination (Saini and Westgate, 2000), panicle exertion (O'Toole and Namuco, 1983), peduncle length (He et al., 2009) and finally are responsible for increased sterility. Drought stress during late panicle development also sharply decreases the percentage of filled grains (Fageria, 2001).

Similar to growth parameters, panicles/ $\mathrm{m}^{2}$, panicle length and spikelets/ panicle increased from 90 to $120 \mathrm{~kg} / \mathrm{N}$ ha applied in fertigation but comparable between 120 and $150 \mathrm{~kg} \mathrm{~N} / \mathrm{ha}$ while sterility of spikelets was more with 90 $\mathrm{kg} \mathrm{N} /$ ha. Test weight was found significantly reduced under $150 \mathrm{~kg} \mathrm{~N} / \mathrm{ha}$ compared to the lower doses during 2011 but remained same with all the $\mathrm{N}$ levels during the second year of study. Increased nitrogen application under fertigation might have led to availability of $\mathrm{N}$ in sufficient quantities required by the crop which encouraged the increased sink formation. These results are in line with the reports of Venugopal (2005), Halder et al., (2008) and Ramesh et al., (2009).

\section{Yield and nitrogen uptake}

Significant increase in grain yield was observed from $100 \%$ PE to $150 \%$ PE (24\%) and then to $200 \%$ PE (24\%) during both the years (Table 3). Similar trend was noticed in straw yield also. Higher harvest index was obtained with irrigating at $200 \%$ PE compared to $100 \%$ PE during first year but not during second year. Grain yield is mostly limited by sink capacity and the ability of grain to accept assimilates (Fukai et al., 1991). Grain yield decreased with the reduced input of water in the present study. This might be because of the negative effect of water stress on photosynthetic process and its partitioning ability towards sink and on the yield components like number of grains and 1000grain weight which was demonstrated in this 
experiment. $\mathrm{N}$ uptake by grain and straw also varied among the irrigation schedules. It was significantly increased with water input increasing from $100 \%$ PE to $200 \%$ PE during both the years of study.

Increasing the nitrogen supply from 90 to 150 $\mathrm{kg} / \mathrm{ha}$ increased the rice yield significantly under fertigation (Table 3). The highest grain yield was recorded at $150 \mathrm{~kg} / \mathrm{ha}$ during both the years. It increased by 13 and 16 per cent during 2011 and 2012, respectively with the application of $120 \mathrm{~kg} \mathrm{~N} /$ ha over $90 \mathrm{~kg} / \mathrm{ha}$. It again increased by 7 and 9 per cent, respectively with $150 \mathrm{~kg}$ / ha compared to 120 $\mathrm{kg} / \mathrm{ha}$. A study conducted by Zhang et al., (2009) in China suggested that in aerobic rice, more carbohydrates from post-anthesis photosynthesis are needed for grain filling.

The regime of fertilizer- $\mathrm{N}$ application needs to promote the contribution of drymatter production between pre-anthesis and postanthesis to achieve a high percentage of filled grains and thus a high harvest index. In another study conducted by Kadiyala et al., (2012) at Hyderabad, 48-58 per cent of applied nitrogen depending on the dose was found to be lost form soil-plant system in aerobic rice. Converting flooded rice to water saving systems such as aerobic system result in high $\mathrm{N}$ losses accompanied by upto 50 per cent reduction in $\mathrm{N}$ use efficiency. Hence, matching $\mathrm{N}$ application to crop demand is the key to reduce $\mathrm{NO}_{3}-\mathrm{N}$ leaching and maintain crop yield (Fang et al., 2006). Fertigation can potentially spoon feed the nutrients to a crop which accurately supplies the crop's nitrogen needs throughout the season, enhance crop yield and reduce the potential for groundwater contamination from nitrates (Lamm et al., 2001). Straw yield and harvest index also followed the similar trend but not differed during first year and second year, respectively. The $\mathrm{N}$ uptake by grain was higher with $150 \mathrm{~kg}$ $\mathrm{N} /$ ha but increased upto $120 \mathrm{~kg} \mathrm{~N} /$ ha only by the straw. The interaction effect between the irrigation schedules and nitrogen levels was not significant in any of the parameters studied.

\section{Water-use efficiency and nitrogen-use efficiency}

Water-use efficiency gradually reduced with increased water input from $100 \%$ PE schedule to $200 \%$ PE but increased with the increase in $\mathrm{N}$ level from 90 to $150 \mathrm{~kg} \mathrm{~N} /$ ha during both the years of study (Table 4).

Similar findings had been brought out by many workers (Shekara et al., 2010 and Sridharan and Vijayalakshmi, 2012). Increase in $\mathrm{N}$ levels from 90 to $150 \mathrm{~kg} \mathrm{~N} / \mathrm{ha}$ through fertigation resulted in higher water productivity which might be attributed to increased yield under higher nitrogen levels with a constant rate of applied water. It was increased by 14.8, 18.0 and 22.2, 27.9 per cent at 120 and $150 \mathrm{~kg}$ compared to $90 \mathrm{~kg} \mathrm{~N} / \mathrm{ha}$ during 2011 and 2012, respectively. This was in agreement with Belder et al., (2005), Maheswari et al., (2008) and Mallareddy et al., (2013).

Nitrogen use efficiency (NUE) (kg grain $/ \mathrm{kg} \mathrm{N}$ applied) of aerobic rice enhanced with the increase in water input from $100 \% \mathrm{PE}$ to $200 \%$ PE through drip irrigation during both the years of study (Table 4). With the increase in the level of nitrogen, NUE gradually decreased in aerobic rice. The highest NUE was recorded with $90 \mathrm{~kg} / \mathrm{ha}$.

The mean NUE of two years with 150 and 120 $\mathrm{kg}$ N/ ha decreased by 26 and 14 per cent, respectively compared to the lower dose. This was in accordance to the statement that crop response to applied nutrients typically follows a diminishing return function as yields approach the potential limit (Hegde et al., 2007). 


\section{Economics}

Gross returns, net returns and benefit: cost ratio were higher in drip irrigation schedule of 200\% PE and $150 \mathrm{~kg} \mathrm{~N} /$ ha closely followed by that realized at $120 \mathrm{~kg} \mathrm{~N} /$ ha in the same irrigation schedule (Table 5). The above economic parameters were lower with $100 \%$ $\mathrm{PE}$ irrigation schedule and $90 \mathrm{~kg} \mathrm{~N} / \mathrm{ha}$.

Higher moisture regime was reported to realize greater net returns and benefit: cost ratio in several studies (Shekara et al., 2010 and Murthy and Reddy, 2013). In general, the net returns and benefit: cost ratio was lower during 2012 despite of increased yield. It was due to the lower minimum support price for the rice grain prevailed in 2012 compared to the same during 2011.

\section{Post-harvest status of available N P K}

Considerable variation in soil available $\mathrm{N}$ status was observed after harvest of rice crop due to different irrigation schedules and nitrogen levels (Table 6).

Soil available $\mathrm{N}$ was higher at increased $\mathrm{N}$ level from 90 to $150 \mathrm{~kg} / \mathrm{ha}$ at all the irrigation schedules, while it decreased from the irrigation schedules of $100 \% \mathrm{PE}$ to $150 \% \mathrm{PE}$ at all the $\mathrm{N}$ levels, during both the years of study. The data also indicated that available $\mathrm{P}$ and $\mathrm{K}$ status of the soil after harvest of rice crop did not differ much due to irrigation schedules or nitrogen levels under drip fertigation.

Table.1 Root volume, root dry weight, days to 50\% flowering in aerobic rice as influenced by irrigation regimes and $\mathrm{N}$ levels through fertigation

\begin{tabular}{|c|c|c|c|c|c|c|}
\hline \multirow[t]{2}{*}{ Treatment } & \multicolumn{2}{|c|}{ Root volume (cc/hill) } & \multicolumn{2}{|c|}{$\begin{array}{l}\text { Root dry weight } \\
\text { (g/hill) }\end{array}$} & \multicolumn{2}{|c|}{$\begin{array}{l}\text { Days to } 50 \% \\
\text { flowering }\end{array}$} \\
\hline & 2011 & 2012 & 2011 & 2012 & 2011 & 2012 \\
\hline \multicolumn{7}{|c|}{ Irrigation regime } \\
\hline $100 \% \mathrm{PE}$ & 22.5 & 18.7 & 7.9 & 6.7 & 95.3 & 95.7 \\
\hline $150 \% \mathrm{PE}$ & 25.6 & 19.2 & 9.1 & 7.6 & 93.7 & 95.1 \\
\hline $200 \%$ PE & 27.7 & 23.5 & 11.4 & 9.0 & 93.9 & 94.6 \\
\hline SEm \pm & 1.00 & 0.62 & 0.28 & 0.16 & 0.81 & 0.53 \\
\hline $\mathrm{CD}(\mathrm{P}=0.05)$ & 3.50 & 2.10 & 1.00 & 0.60 & NS & NS \\
\hline \multicolumn{7}{|l|}{ N level (kg/ha) } \\
\hline 90 & 21.3 & 18.2 & 8.1 & 7.0 & 94.6 & 94.9 \\
\hline 120 & 24.4 & 20.9 & 9.6 & 7.7 & 95.2 & 95.2 \\
\hline 150 & 30.0 & 22.3 & 10.7 & 8.7 & 93.2 & 95.3 \\
\hline SEm \pm & 0.70 & 0.62 & 0.26 & 0.15 & 0.46 & 0.32 \\
\hline $\mathrm{CD}(\mathrm{P}=0.05)$ & 2.10 & 1.90 & 0.80 & 0.40 & 1.40 & NS \\
\hline \multicolumn{7}{|l|}{ Interaction } \\
\hline SEm \pm & 1.74 & 1.08 & 0.49 & 0.28 & 1.41 & 0.92 \\
\hline $\mathrm{CD}(\mathrm{P}=\mathbf{0 . 0 5})$ & NS & NS & NS & NS & NS & NS \\
\hline
\end{tabular}


Table. 2 Yield attributes of aerobic rice as influenced by irrigation regimes and $\mathrm{N}$ levels through fertigation

\begin{tabular}{|c|c|c|c|c|c|c|c|c|c|c|}
\hline \multirow[t]{2}{*}{ Treatment } & \multicolumn{2}{|c|}{ Panicles $/ \mathrm{m}^{2}$} & \multicolumn{2}{|c|}{$\begin{array}{l}\text { Panicle length } \\
\quad(\mathrm{cm})\end{array}$} & \multicolumn{2}{|c|}{$\begin{array}{c}\text { Filled } \\
\text { spikelets/panicle }\end{array}$} & \multicolumn{2}{|c|}{ Sterility (\%) } & \multicolumn{2}{|c|}{ Test weight (g) } \\
\hline & 2011 & 2012 & 2011 & 2012 & 2011 & 2012 & 2011 & 2012 & 2011 & 2012 \\
\hline \multicolumn{11}{|l|}{ Irrigation regime } \\
\hline $100 \% \mathrm{PE}$ & 221 & 233 & 21.3 & 22.3 & 146 & 122 & 15.5 & 12.4 & 16.8 & 16.9 \\
\hline $150 \% \mathrm{PE}$ & 249 & 263 & 23.1 & 22.0 & 197 & 167 & 10.6 & 11.3 & 17.1 & 17.6 \\
\hline $200 \% \mathrm{PE}$ & 290 & 306 & 23.8 & 23.6 & 215 & 209 & 11.0 & 9.1 & 17.1 & 17.2 \\
\hline SEm \pm & 11.8 & 12.4 & 0.70 & 0.51 & 9.3 & 10.8 & 0.99 & 0.49 & 0.11 & 0.20 \\
\hline $\mathrm{CD}(\mathrm{P}=0.05)$ & 41.0 & 43.0 & NS & NS & 32.0 & 37.0 & 3.40 & 1.70 & NS & NS \\
\hline \multicolumn{11}{|l|}{ N level $(\mathrm{kg} / \mathrm{ha})$} \\
\hline 90 & 224 & 236 & 20.9 & 20.8 & 166 & 147 & 14.0 & 12.4 & 12.4 & 17.1 \\
\hline 120 & 253 & 267 & 23.0 & 23.0 & 185 & 168 & 11.9 & 10.6 & 10.6 & 17.4 \\
\hline 150 & 283 & 298 & 24.3 & 24.1 & 207 & 182 & 11.2 & 9.8 & 9.8 & 17.2 \\
\hline SEm \pm & 10.5 & 11.1 & 0.26 & 0.75 & 7.0 & 6.9 & 0.72 & 0.39 & 0.39 & 0.20 \\
\hline $\mathrm{CD}(\mathrm{P}=0.05)$ & 31.0 & 33.0 & 0.80 & 2.20 & 21.0 & 21.0 & 2.10 & 1.20 & 1.20 & NS \\
\hline \multicolumn{11}{|l|}{ Interaction } \\
\hline SEm \pm & 20.4 & 21.5 & 1.20 & 0.88 & 16.1 & 18.6 & 1.72 & 0.85 & 0.19 & 0.35 \\
\hline $\mathrm{CD}(\mathrm{P}=0.05)$ & NS & NS & NS & NS & NS & NS & NS & NS & NS & NS \\
\hline
\end{tabular}

Table.3 Yield, harvest index and $\mathrm{N}$ uptake of aerobic rice as influenced by irrigation regimes and $\mathrm{N}$ levels through fertigation

\begin{tabular}{|c|c|c|c|c|c|c|c|c|c|c|}
\hline \multirow[t]{2}{*}{ Treatment } & \multicolumn{2}{|c|}{$\begin{array}{l}\text { Grain yield } \\
\text { (kg/ha) }\end{array}$} & \multicolumn{2}{|c|}{$\begin{array}{c}\text { Straw yield } \\
\text { (kg/ha) }\end{array}$} & \multicolumn{2}{|c|}{ Harvest Index } & \multicolumn{2}{|c|}{$\begin{array}{l}\text { N uptake by } \\
\text { grain }(\mathrm{kg} / \mathrm{ha})\end{array}$} & \multicolumn{2}{|c|}{$\begin{array}{l}\text { N uptake by } \\
\text { straw (kg/ha) }\end{array}$} \\
\hline & 2011 & 2012 & 2011 & 2012 & 2011 & 2012 & 2011 & 2012 & 2011 & 2012 \\
\hline \multicolumn{11}{|c|}{ Irrigation regime } \\
\hline $100 \% \mathrm{PE}$ & 2474 & 3048 & 3664 & 5557 & 40.2 & 40.1 & 28.4 & 33.4 & 20.8 & 33.2 \\
\hline $150 \% \mathrm{PE}$ & 3263 & 3540 & 4837 & 6852 & 40.4 & 41.3 & 41.7 & 45.3 & 27.3 & 42.7 \\
\hline $200 \%$ PE & 4073 & 4349 & 5783 & 8979 & 42.6 & 42.3 & 59.5 & 60.6 & 35.4 & 61.2 \\
\hline SEm \pm & 158.1 & 142.4 & 218.9 & 374.8 & 0.58 & 0.56 & 2.52 & 2.53 & 0.92 & 4.03 \\
\hline $\mathrm{CD}(\mathrm{P}=0.05)$ & 546 & 492 & 756 & 1294 & 2.0 & NS & 8.7 & 8.7 & 3.2 & 13.9 \\
\hline \multicolumn{11}{|l|}{ N level (kg/ha) } \\
\hline 90 & 2998 & 3199 & 4508 & 5954 & 39.8 & 39.6 & 37.4 & 37.4 & 24.2 & 38.8 \\
\hline 120 & 3385 & 3711 & 4793 & 7301 & 41.3 & 41.5 & 43.3 & 47.0 & 28.2 & 41.5 \\
\hline 150 & 3628 & 4027 & 4984 & 8133 & 42.1 & 42.6 & 48.9 & 55.0 & 31.1 & 56.8 \\
\hline SEm \pm & 72.1 & 85.5 & 156.0 & 225.1 & 0.63 & 0.58 & 1.71 & 1.86 & 1.19 & 3.16 \\
\hline $\mathrm{CD}(\mathrm{P}=\mathbf{0 . 0 5})$ & 214 & 254 & NS & 669 & 1.90 & 1.70 & 5.10 & 5.50 & 3.60 & 9.40 \\
\hline \multicolumn{11}{|l|}{ Interaction } \\
\hline SEm \pm & 273.8 & 246.7 & 379.2 & 649.2 & 1.01 & 0.96 & 4.37 & 4.39 & 1.9 & 6.98 \\
\hline $\mathrm{CD}(\mathrm{P}=0.05)$ & NS & NS & NS & NS & NS & NS & NS & NS & NS & NS \\
\hline
\end{tabular}


Table.4 Water- and nitrogen use efficiency of aerobic rice as influenced by irrigation regimes and $\mathrm{N}$ levels through fertigation

\begin{tabular}{|l|r|r|r|r|}
\hline Treatment & \multicolumn{2}{|c|}{ WUE (kg/ha-mm) } & \multicolumn{2}{c|}{$\begin{array}{c}\text { NUE (kg grain/kg N } \\
\text { applied) }\end{array}$} \\
\cline { 2 - 5 } & $\mathbf{2 0 1 1}$ & $\mathbf{2 0 1 2}$ & $\mathbf{2 0 1 1}$ & $\mathbf{2 0 1 2}$ \\
\hline \multicolumn{5}{|c|}{ Irrigation regime } \\
\hline $\mathbf{1 0 0 \%}$ PE & 6.1 & 7.7 & 20.95 & 25.69 \\
\hline $\mathbf{1 5 0 \%}$ PE & 5.9 & 6.8 & 28.10 & 30.19 \\
\hline $\mathbf{2 0 0 \%}$ PE & 5.8 & 6.7 & 36.66 & 37.44 \\
\hline & & & & \\
\hline N level (kg/ha) & & & & \\
\hline $\mathbf{9 0}$ & 5.4 & 6.1 & 33.31 & 35.55 \\
\hline $\mathbf{1 2 0}$ & 6.2 & 7.2 & 28.21 & 30.92 \\
\hline $\mathbf{1 5 0}$ & 6.6 & 7.8 & 24.18 & 26.85 \\
\hline
\end{tabular}

Table.5 Economics of aerobic rice as influenced by the irrigation schedules and $\mathrm{N}$ levels through fertigation

\begin{tabular}{|c|c|c|c|c|c|c|c|}
\hline \multicolumn{2}{|c|}{ Treatment } & \multicolumn{3}{c|}{2011} & \multicolumn{3}{c|}{2012} \\
\hline $\begin{array}{c}\text { Irrigation } \\
\text { regime }\end{array}$ & $\begin{array}{c}\text { Nitrogen } \\
\text { level } \\
\text { (kg/ha) }\end{array}$ & $\begin{array}{c}\text { Gross } \\
\text { returns } \\
\text { (₹ /ha) }\end{array}$ & $\begin{array}{c}\text { Net } \\
\text { returns } \\
\text { (₹ /ha) }\end{array}$ & $\begin{array}{c}\text { Benefit: } \\
\text { cost } \\
\text { ratio }\end{array}$ & $\begin{array}{c}\text { Gross } \\
\text { returns } \\
\text { (₹ /ha) }\end{array}$ & $\begin{array}{c}\text { Net } \\
\text { returns } \\
\text { (₹ /ha) }\end{array}$ & $\begin{array}{c}\text { Benefit: } \\
\text { cost } \\
\text { ratio }\end{array}$ \\
\hline $\mathbf{1 0 0} \%$ PE & 90 & 30410 & 5787 & 0.24 & 31093 & 6470 & 0.26 \\
\hline & 120 & 41944 & 16944 & 0.68 & 40378 & 15378 & 0.62 \\
\hline & 150 & 42637 & 17260 & 0.68 & 47052 & 21675 & 0.85 \\
\hline $\mathbf{1 5 0} \%$ PE & 90 & 48156 & 23433 & 0.95 & 39181 & 14458 & 0.58 \\
\hline & 120 & 46161 & 24061 & 0.96 & 48718 & 23618 & 0.94 \\
\hline & 150 & 52179 & 26702 & 1.05 & 50083 & 24606 & 0.97 \\
\hline $\mathbf{2 0 0} \%$ PE & 90 & 56578 & 31755 & 1.28 & 49623 & 24800 & 1.00 \\
\hline & 120 & 62374 & 37174 & 1.48 & 54687 & 29487 & 1.17 \\
\hline & 150 & 66989 & 41412 & 1.62 & 59297 & 33720 & 1.32 \\
\hline & & & & & & & \\
\hline
\end{tabular}

Price (2011): Grain- ₹ 13.1/kg ; Straw: ₹ $1.0 / \mathrm{kg}$

Price (2012): Grain- ₹ 10.8 /kg; Straw: ₹ $1.0 / \mathrm{kg}$ 
Table.6 Soil N P K status (kg/ha) after harvest of rice crop as influenced by the irrigation schedules and $\mathrm{N}$ levels through fertigation

\begin{tabular}{|r|r|c|c|c|c|c|c|}
\hline \multicolumn{2}{|c|}{ Treatment } & \multicolumn{3}{|c|}{2011} & \multicolumn{2}{c|}{2012} \\
\hline $\begin{array}{c}\text { Irrigation } \\
\text { schedule }\end{array}$ & $\begin{array}{c}\text { Nitrogen } \\
\text { level } \\
\text { (kg/ha) }\end{array}$ & N & P & K & N & P & K \\
\hline $\mathbf{1 0 0} \%$ PE & 90 & 258.6 & 11.5 & 74.1 & 245.9 & 13.2 & 64.9 \\
\hline & 120 & 263.6 & 10.8 & 68.8 & 250.4 & 10.2 & 65.5 \\
\hline & 150 & 303.2 & 10.2 & 66.4 & 321.5 & 10.8 & 68.4 \\
\hline $\mathbf{1 5 0} \%$ PE & 90 & 243.3 & 10.8 & 71.1 & 215.4 & 10.4 & 58.8 \\
\hline & 120 & 261.7 & 9.7 & 64.5 & 231.7 & 9.8 & 56.6 \\
\hline & 150 & 288.7 & 9.6 & 58.3 & 283.6 & 9.4 & 58.1 \\
\hline $\mathbf{2 0 0} \%$ PE & 90 & 218.6 & 10.1 & 62.8 & 133.4 & 8.8 & 59.2 \\
\hline & 120 & 234.7 & 9.8 & 58.7 & 185.8 & 8.5 & 58.1 \\
\hline & 150 & 256.4 & 8.4 & 54.4 & 188.6 & 8.3 & 56.6 \\
\hline
\end{tabular}

Fig.1 Plant height $(\mathrm{cm})$ of aerobic rice at different growth stages as influenced by irrigation regimes under drip irrigation
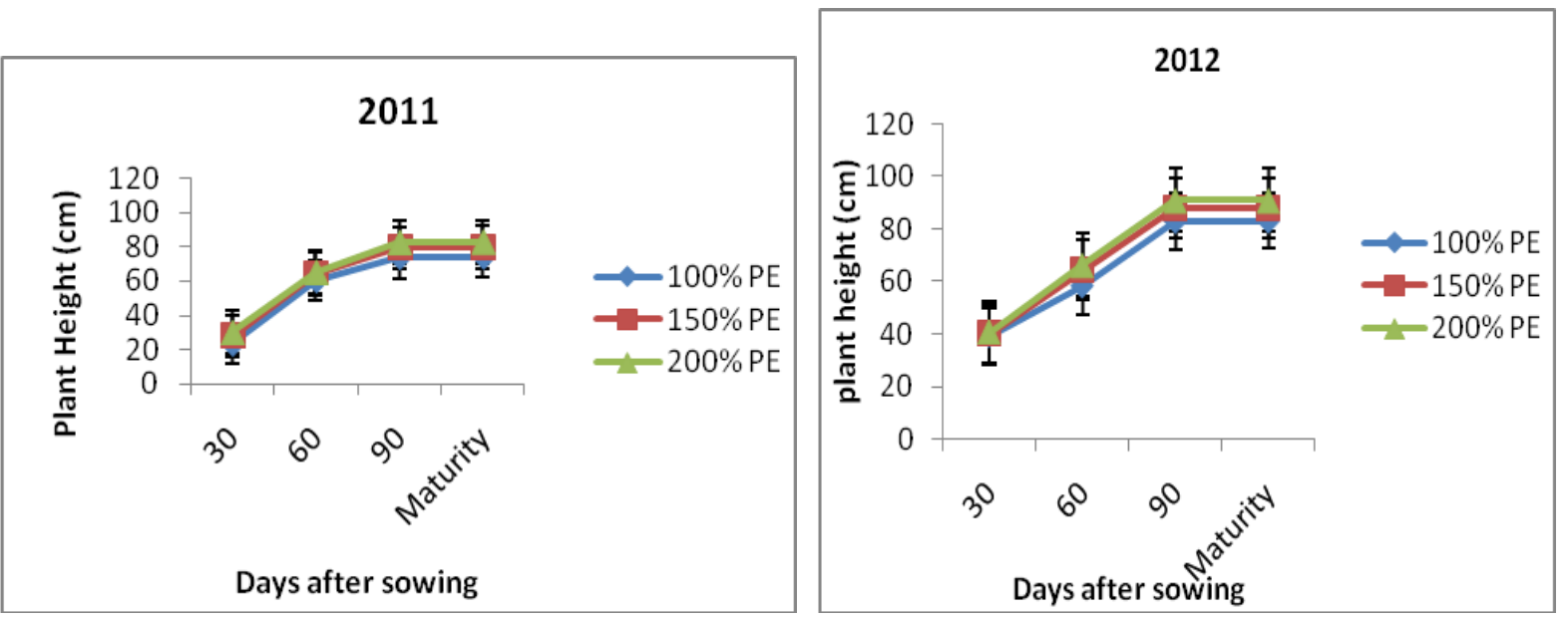
Fig.2 Leaf Area Index of aerobic rice at different growth stages as influenced by irrigation regimes under drip irrigation
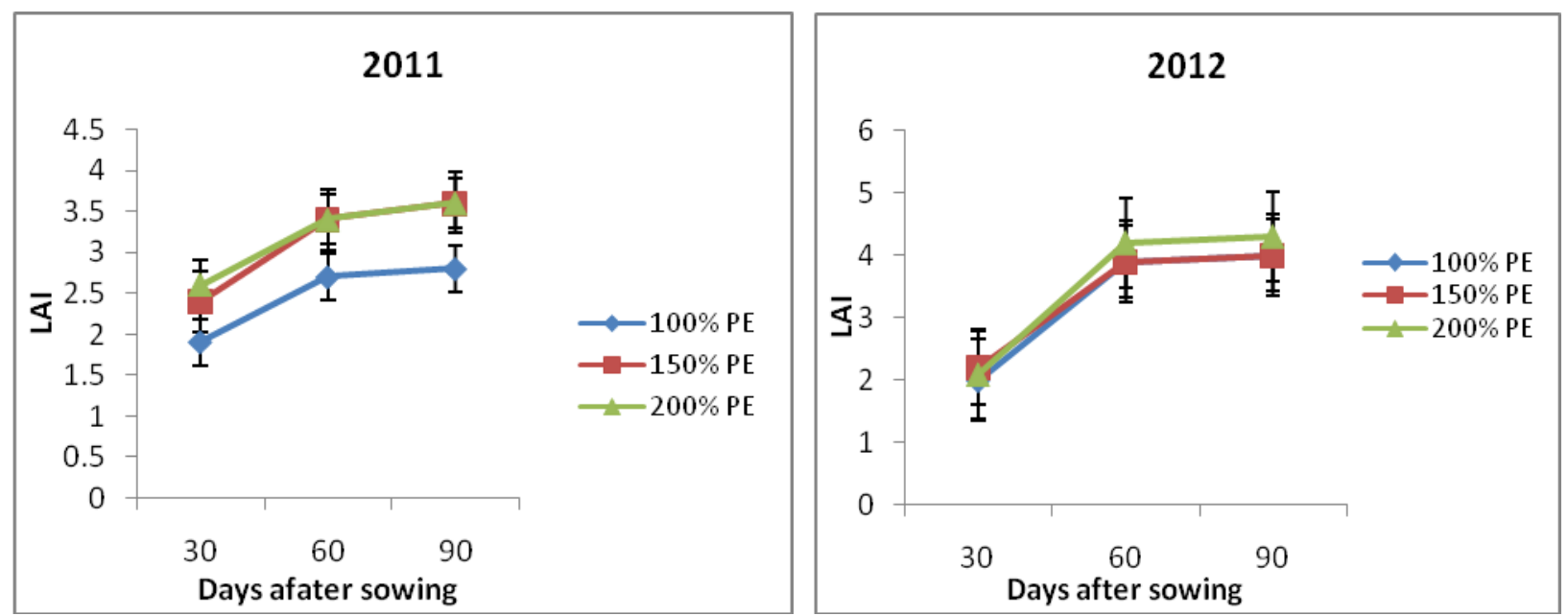

Fig.3 Tiller production of aerobic rice at different growth stages as influenced by irrigation regimes under drip irrigation
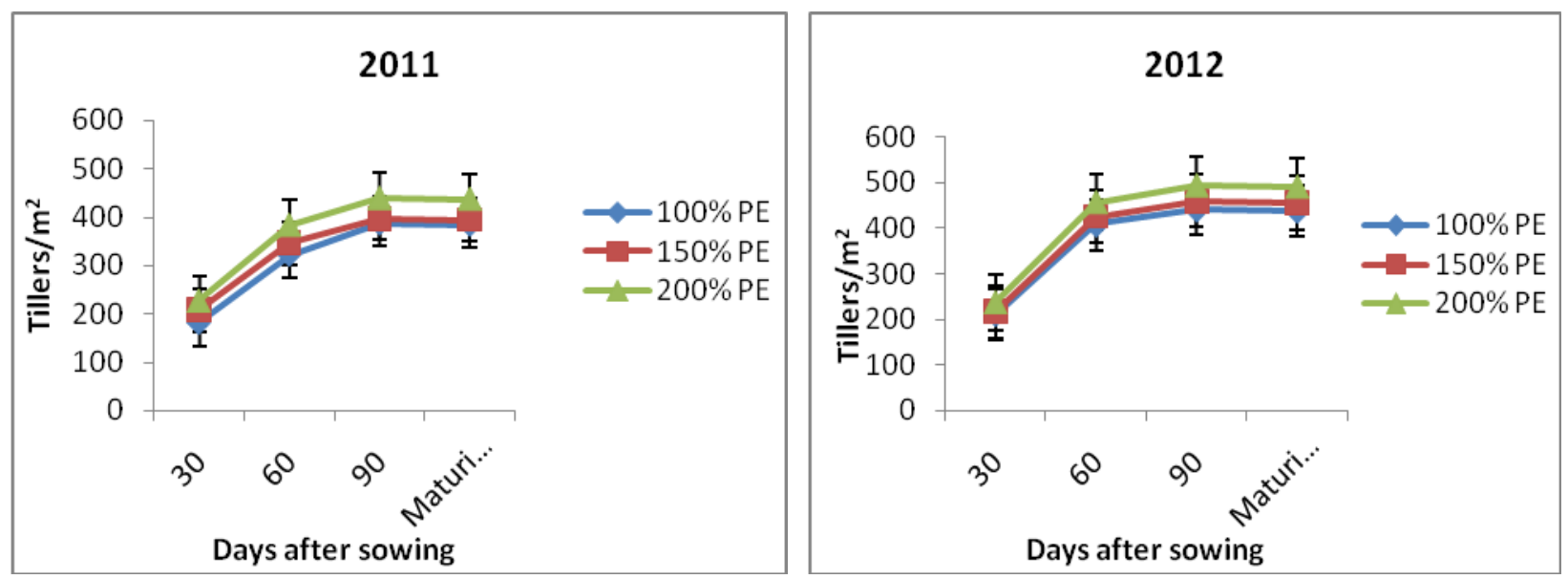

Fig.4 SPAD meter reading of aerobic rice at different growth stages as influenced by irrigation regimes under drip irrigation
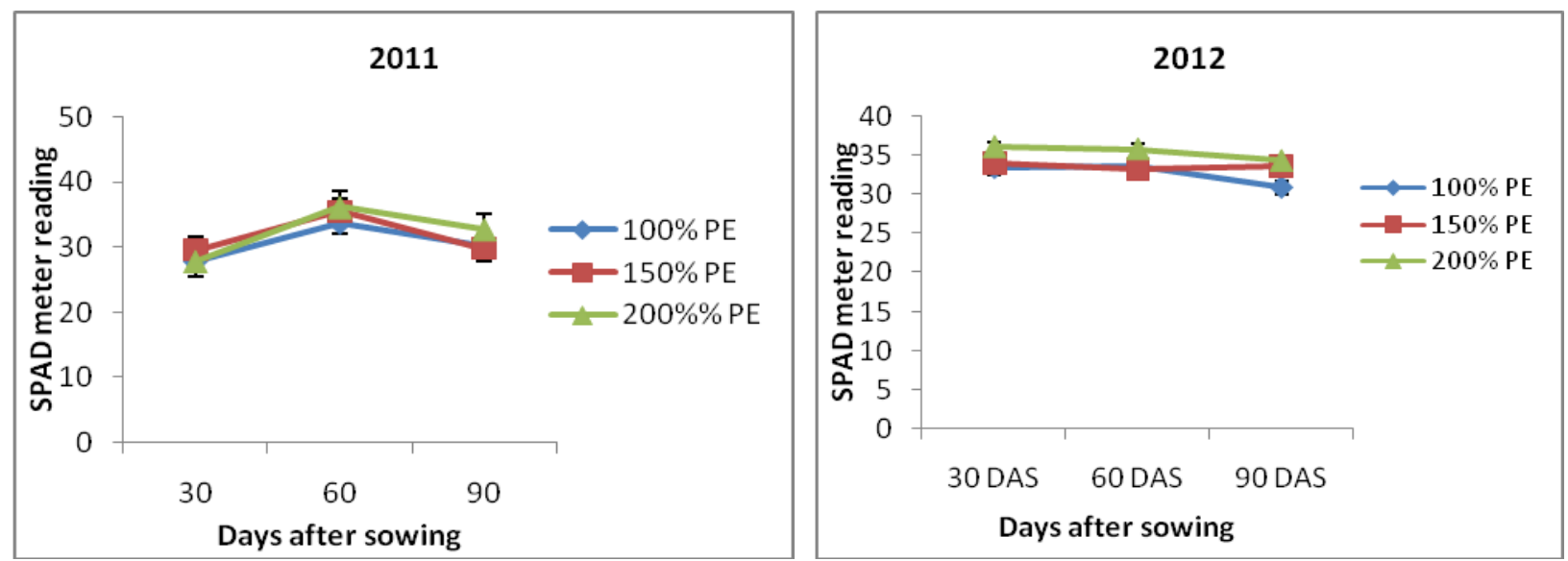
Fig.5 Drymatter production $(\mathrm{kg} / \mathrm{ha})$ of aerobic rice at different growth stages as influenced by irrigation regimes under drip irrigation
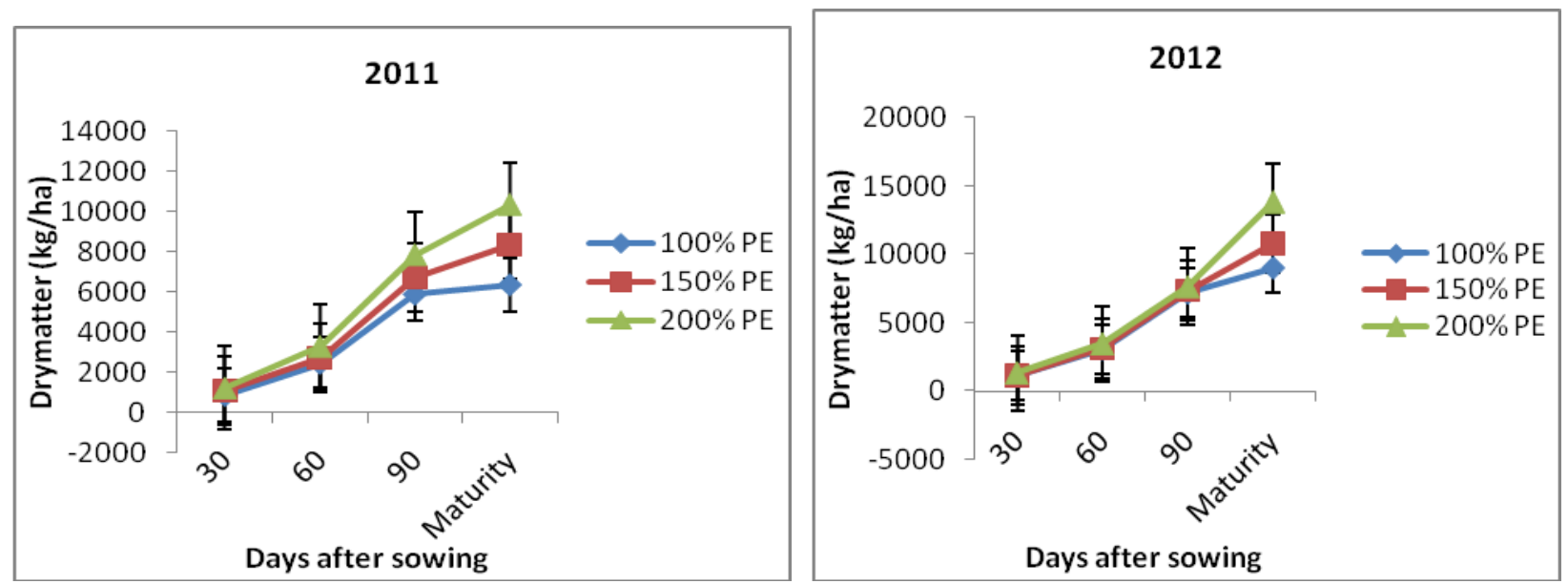

Fig.6 Plant height $(\mathrm{cm})$ of aerobic rice at different growth stages as influenced by nitrogen fertigation
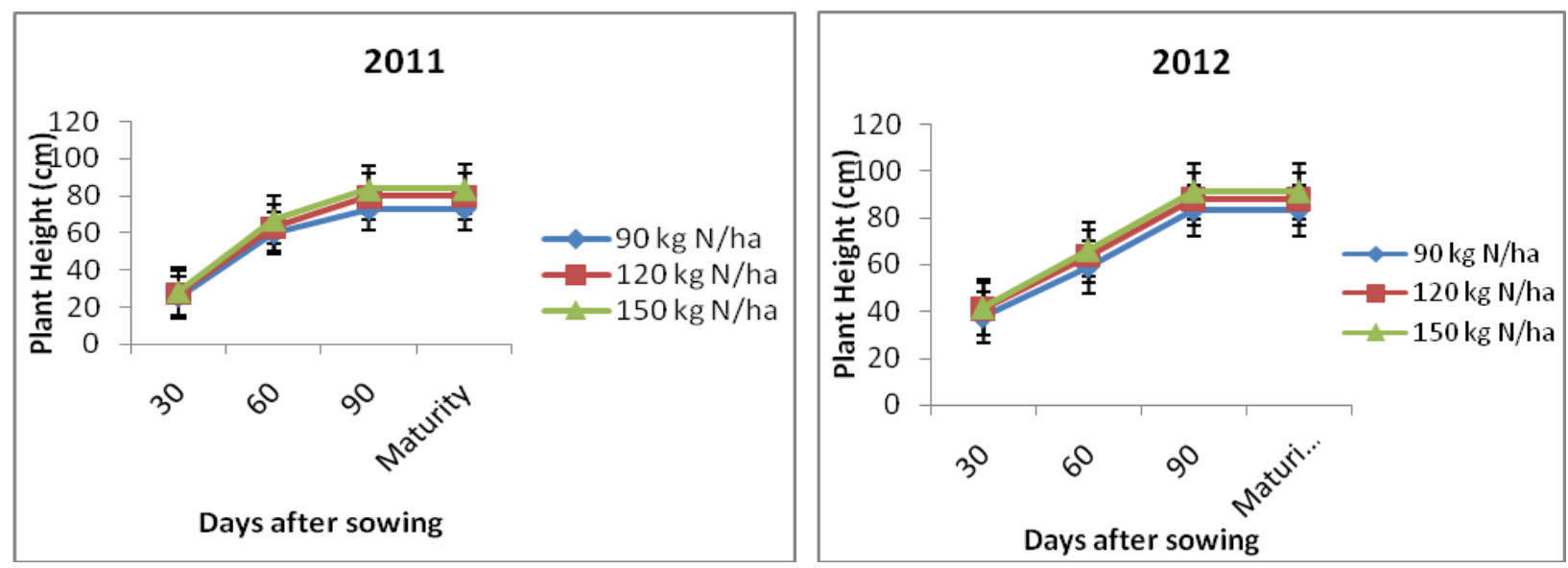

Fig.7 Leaf Area Index of aerobic rice at different growth stages as influenced by nitrogen fertigation
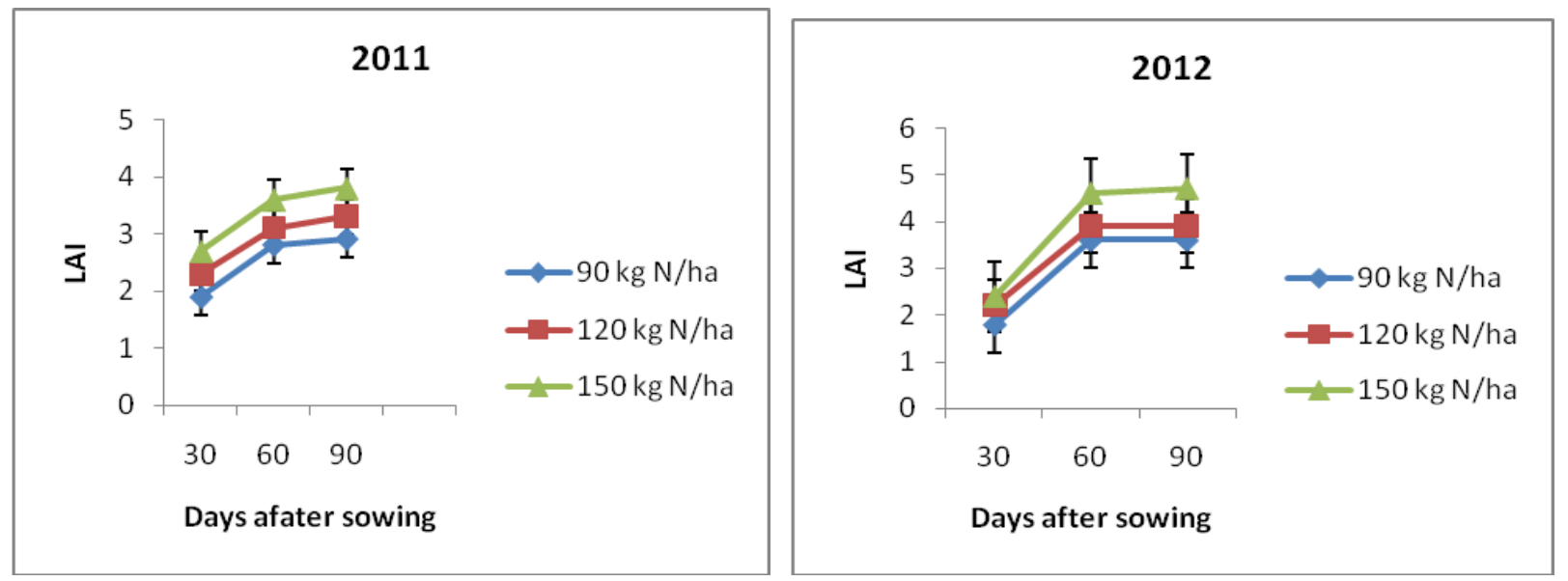
Fig.8 Tiller production of aerobic rice at different growth stages as influenced by nitrogen fertigation
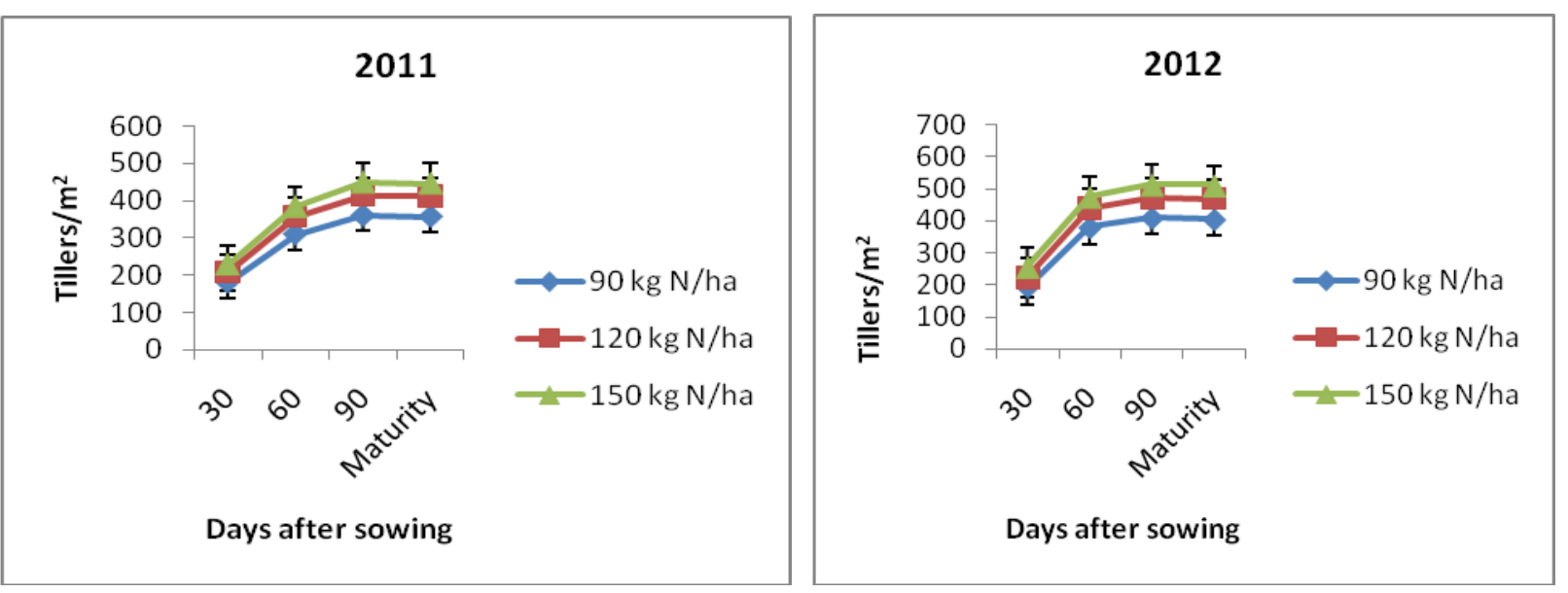

Fig.9 SPAD meter reading of aerobic rice at different growth stages as influenced by nitrogen fertigation
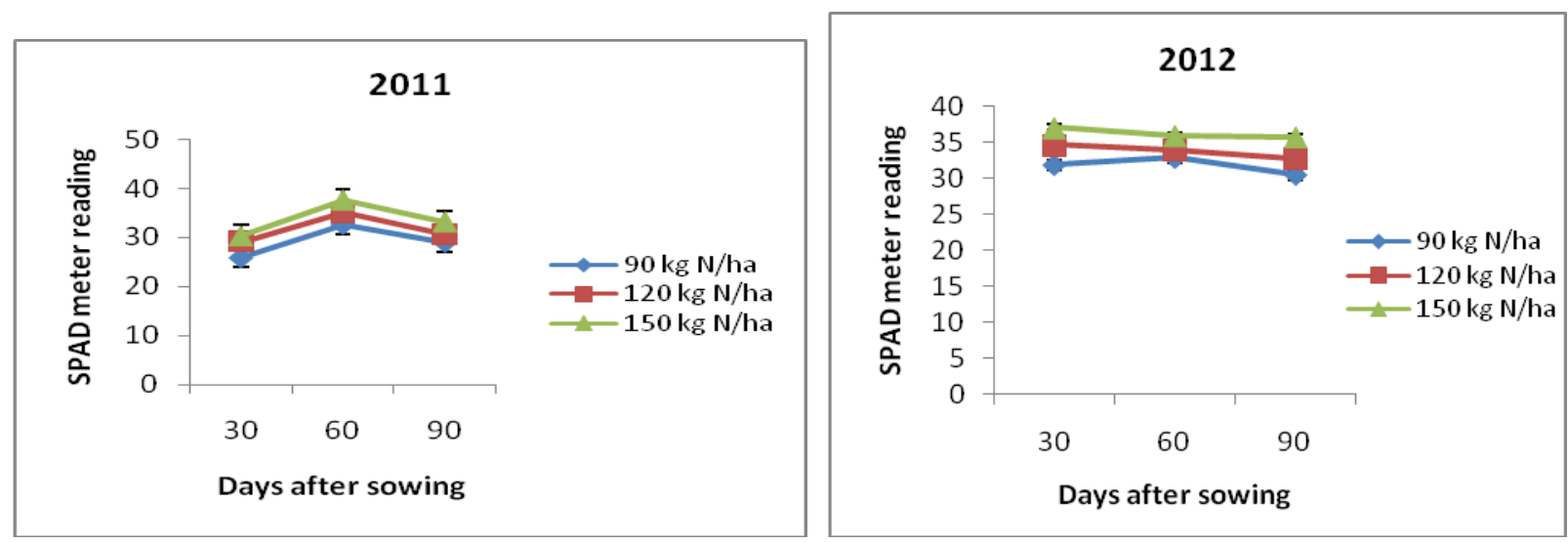

Fig.10 Drymatter production $(\mathrm{Kg} / \mathrm{ha})$ of aerobic rice at different growth stages as influenced by nitrogen fertigation
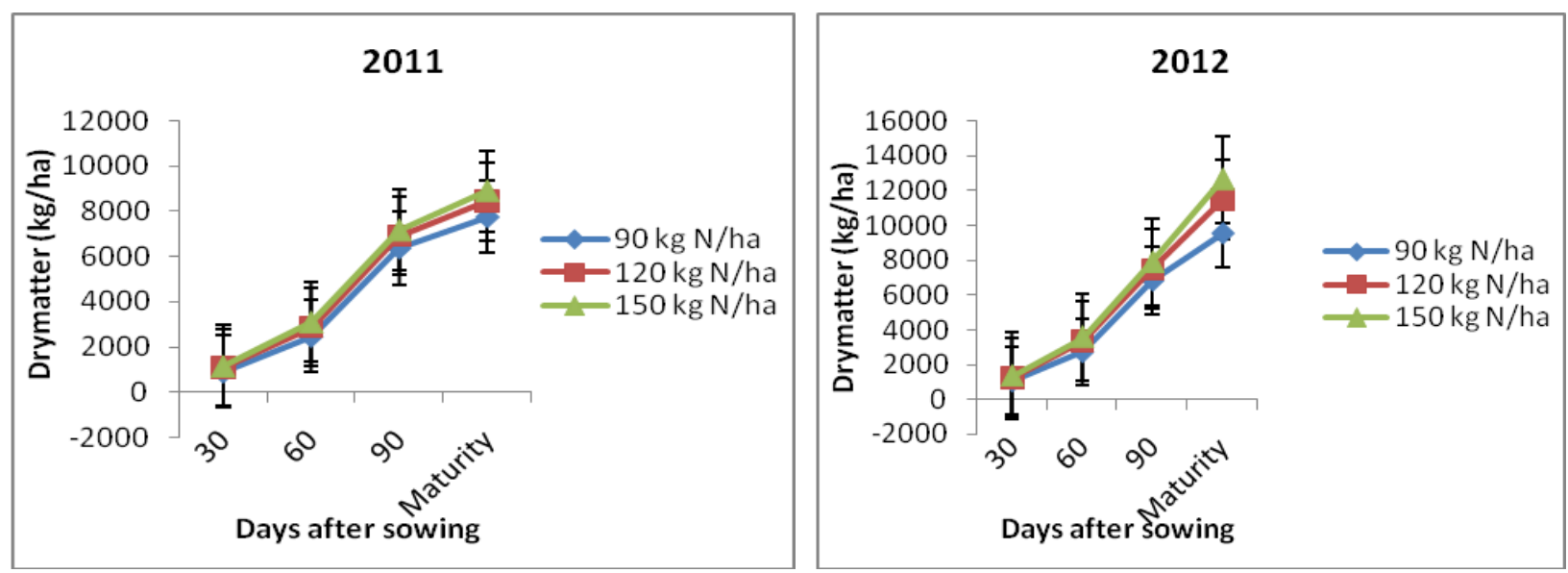
From the present study, we conclude that growing aerobic rice under drip irrigation by replenishing the water twice that evaporated from open pan (200\% PE) along with fertigation at $150 \mathrm{~kg} \mathrm{~N} / \mathrm{ha}$ appears to increase the yields of rice under aerobic system thus helping to bridge the gap between flooded and aerobic cultivation.

\section{Acknowledgements}

My earnest acknowledgment must go to Dr. M. Malla Reddy for his scholastic guidance, unceasing interest, valuable knowledge and technical advice.

\section{References}

Barker, R., Dawe, D., Tuong, T.P., Bhuiyan, S.I. and Guerra, L.C. 1999. The outlook for water resources in rice production. In Assessment and Orientation towards the $21^{\text {st }}$ century. Proceedings of the $19^{\text {th }}$ session of the International Rice Commission. 7-9 September 1998. Cairo, Egypt.

Belder, P., Bouman, B.A.M., Spiertz, J.H.J., Peng, S., Castaneda, A.R. and Visperas, R.M. 2005. Crop performance, nitrogen and water use in flooded and aerobic rice. Plant and Soil 273: 167-182.

Bouman, B.A.M. and Tuong, T.P. 2001. Field water management to save water and increase its productivity in irrigated rice. Agricultural Water Management 49: 11-30.

De Datta, S.K. 1989. Spikelet sterility and flowering response of rice to water stress at anthesis. Annals of Botany 63: 257-264.

Ekanayake, I.J., Steponkus, P.L. and De Datta, S.K. 1990. Sensitivity of pollination to water deficits at anthesis in upland rice. Crop Science 30: 310315.
Fageria, N.K. 2001. Nutrient management for improving upland rice productivity and sustainability. Communications to Soil Science Plant Annals 32: 26032629.

Fang, Q., Yu, Q., Wang, E., Chen, Y., Zhang, G., Wang, J. and Li, L. 2006. Soil nitrate accumulation, leaching and crop nitrogen use as influenced by fertilization and irrigation in an intensive wheat-maize double cropping system in the North China Plain. Plant Soil 284: 335-350.

Farooq, M., Kabayashi, N., Wahid, A., Ito, O. and Basra, S.M.A. 2009. Strategies for producing more rice with less water. Advances in Agronomy 101: 351-388.

Fukai, S., Li, L., Vizmonte, P.T. and Fisher, K.S. 1991. Control of grain yield by sink capacity and assimilate supply in various rice cultivars. Experimental Agriculture 27: 127-135.

George, T., Magbanua, R., Garrity, D.P., Tubana, B.S. and Quiton, J. 2002. Rapid yield loss of rice cropped usefully in aerobic soil. Agronomy Journal 94: 981-989.

Ghosh, A., Dey, R. and Singh, O.N. 2012. Improved management alleviating impact of water stress on yield decline of tropical aerobic rice. Agronomy Journal 104: 584-588.

Halder, J., Nayak, R.N. and Saho, K.C. 2008. Nitrogen management in rainfed direct seeded upland rice. Annals of Agricultural Research 29 (1, 2, 3 \& 4): 15-20.

He, H., Serraj, R. and Yang, Q. 2009. Changes in OsXTH gene expression, ABA content, and peduncle elongation in rice subjected to drought at the reproductive stage. Acta Physiology of Plant 31: 749-756.

Hegde, D.M., Babu, S.N.S., Qureshi, A.A. and Murthy, I.Y.L.N. 2007. Enhancing nutrient-use efficiency in crop 
production - a review. Indian Journal of Agronomy 52 (4): 261-274.

Henry, A., Veresh, R.P., Ronaldo, G., Torres, O., Macnely, K. L. and Serra, R. 2011. Variation in root system architecture and drought response in rice (Oryza sativa) phenotyping of the Oryza SNP panel in rainfed lowland. Field Crop Research 120: 205-214.

Joshi, R., Mani, S.C., Shukla, A. and Pant, R.C. 2009. Aerobic rice: Water use sustainability. Oryza 46 (1): 1-5.

Kadiyala, M.D.M., Mylavarapu, R.S., Li, Y.C., Reddy, G.B. and Reddy, M.D. 2012. Impact of aerobic rice cultivation on growth, yield and water productivity of rice-maize rotation in Semiarid Tropics. Agronomy Journal 104 (6):1757-1765.

Kato, Y., Kamoshita, A., Abe, J., Imoto, H. and Yamagishi, J. 2007. Growth of rice cultivars under upland condition with different levels of water supply. Root system development, water extraction and plant water status. Plant Production Science 10: 3-13.

Lamm, F.R., Trooien, T.P., Manaes, H.L. and Sunderman, H.D. 2001. Nitrogen fertilization for subsurface dripirrigated corn. Transactions of the ASAE 44 (3): 533-542.

Mahajan, G., Chauhan, B.S., Timsina, J., Singh, P.P. and Singh, K. 2012. Crop performance and water and nitrogen use efficiencies in dry-seeded rice in response to irrigation and fertilizer amounts in northwest India. Field Crops Research 134: 59-70.

Maheswari, J., Bose, J., Sangeetha, S.P., Sanjutha, S. and Priya, R. S. 2008. Irrigation regimes and $\mathrm{N}$ levels influence chlorophyll, leaf area index, proline and soluble protein content of aerobic rice (Oryza sativa L.). International Journal of Agricultural Research 3 (4): 307-316.
Mallareddy, M. and Padmaja, B. 2013. Response of rice (Oryza sativa) varieties to nitrogen under aerobic and flooded conditions. Indian Journal of Agronomy 58 (4): 500-505.

Mallareddy, M., Padmaja, B., Veeranna, G. and Reddy, V.V. 2013. Response of aerobic rice to irrigation scheduling and nitrogen doses under drip irrigation. Journal of Research, ANGRAU 41 (2): 144-148.

Misra, R. and Ahmed, M. 1987. Root parameters and their measurement. In Mannual of Irrigation Agronomy. 319326.

Murthy, K.V.R. and Reddy, D.S. 2013. Effect of irrigation and weed management practices on nutrient uptake and economics of aerobic rice. IOSR Journal of Agriculture and Veterinary Science (IOSR-JAVS) 3 (1): 15-21.

O'Toole, J.C. and Namuco, O.S. 1983. Role of panicle exsertion in stress induced sterility. Crop Science 23: 1093-1097.

Panse, V.G. and Sukhatme, P.V. 1985. Statistical Methods for Agricultural Workers, $4^{\text {th }}$ enlarged edition, Indian Council of Agricultural Research, New Delhi.

Parthasarathi, T., Vanitha, K., Lakshamanakuniar, P. and Kalaiyarasi, D. 2012. Aerobic ricemitigating water stress for the future climate change. International Journal of Agronomy and Plant Production 3 (7):241-254.

Peng, S., Bouman, B.A.M., Visperas, R.M., Castaneda, A.R., Nie, L. and Park, H. 2006. Comparision between aerobic and flooded rice in the tropics; agronomic performance in an eightseason experiment. Field Crops Research 96: 252-259.

Peng, S. and Bouman, B.A.M. 2007. Prospects for genetic improvement to increase lowland rice yields with less 
water and nitrogen. In J. Spiertz (eds.) - Scale and complexity in plant systems research - Gene-plant relations, pp 251-266.Springer, London.

Peng, N.L., Bing, S., Chen, M.X., Shah, F., Huang, J.L., Cui, K.H. and Jing, X. 2012. Aerobic rice for water-saving agriculture-A review. Agronomy for Sustainable Development 32 (2):411418.

Prasad, R. 2011. Aerobic rice systems. Advances in Agronomy 111: 207-247.

Ramesh, T., Sathiya, K., Padmanabhan, P.K. and Martin, J.M. 2009. Optimization of nitrogen and suitable weed management practice for aerobic rice. Madras Agricultural Journal 96 (712): 344-348.

Richards, R. 2008. Genetic opportunities to improve cereal root system for dryland agriculture. Plant Production Science 11: $12-16$.

Saini, H.S. and Westgate, M.E. 2000. Reproductive development in grain crops during drought. Advances in Agronomy 68:59-96.

Sathiya, K., Sathyamoorthi, K. and Martin, G.J. 2008. Effect of nitrogen levels and split doses on the productivity of aerobic rice. Research on Crops 9 (3): 527-530.
Shekara, B.G., Sharanappa. and Krishnamurthy, N. 2010. Effect of irrigation schedules on growth and yield of aerobic rice (Oryza sativa) under varied levels of farmyard manure in Cauvery command area. Indian Journal of Agronomy 55 (1): 35-39.

Singh, A.K. 2004. Enhancing water use efficiency in rice. In International Symposium on Rice: From green Revolution to Gene Revolution, Extended Summaries, Vol. I. October, 4-6, 2004, Directorate of Rice Research, Rajendranagar, Hyderabad, India. 13.

Sridharan, N. and Vijayalakshmi, C. 2012. Crop performance, nitrogen and water use in aerobic rice cultivation. Plant Archives. 12 (1):79-83.

Zhang, Q.C and Wang, X. 2002. Optimal nitrogen application for direct seeding early rice. China Journal Rice Science 16: 346-350.

Zhang, L., Lin, S., Bouman, B.A.M., Xue, C., Wei, F., Tao, H., Yang, X., Wang, H., Zhao, D. and Dittert, K. 2009. Response of aerobic rice growth and grain yield of $\mathrm{N}$ fertilizer at two contrasting sites near Beijing, China. Field Crops Research 114: 45-53.

\section{How to cite this article:}

Padmaja, B. and Malla Reddy, M. 2018. Drip Irrigation and Fertigation Effects on Aerobic Rice (Oryza sativa) in Semi-Arid Conditions of Telangana State, India. Int.J.Curr.Microbiol.App.Sci. 7(08): 1156-1171. doi: https://doi.org/10.20546/ijcmas.2018.708.131 